\title{
Life Expectancy of Population of the Country: The Role of Health Services Effectiveness
}

\author{
V. Babenko ${ }^{1}$, M. Nehrey ${ }^{2}$, E. Gaponova ${ }^{3}$, N. Ryzhikova ${ }^{4} \&$ E. Zaporozhets ${ }^{5}$ \\ ${ }^{1}$ Department of International E-Commerce and Hotel \& Restaurant Business, V. N. Karazin Kharkiv National \\ University, Kharkiv, Ukraine \\ 2 Department of Economic Cybernetics, National University of Life and Environment Science of Ukraine, Kyiv, \\ Ukraine \\ ${ }^{3}$ Department of Social Sciences, Kharkiv National Medical University, Kharkiv, Ukraine \\ ${ }^{4}$ Department of Accounting and Audit, Kharkiv Petro Vasylenko National Technical University of Agriculture, \\ Kharkiv, Ukraine \\ ${ }^{5}$ Odessa Customs of the State Fiscal Service of Ukraine, Advisor to the Tax and Customs Service of Ukraine, \\ Odessa, Ukraine \\ Correspondence: V. Babenko, Department of International E-Commerce and Hotel \& Restaurant Business, V. N. \\ Karazin Kharkiv National University, Kharkiv, Ukraine. E-mail: vitalinababenko@karazin.ua
}

Received: November 5, 2019

Accepted: November 15, 2019

Online Published: December 22, 2019

doi:10.5430/rwe.v10n4p86

URL: https://doi.org/10.5430/rwe.v10n4p86

\begin{abstract}
The impact of health care on life expectancy of population in different countries has been studied. The subject of the study was analysis of efficiency of public health expenditures and their percentage of Gross Domestic Product. The authors employed a relatively new method of comparative analysis, Data Envelopment Analysis (DEA), which involves to measure technical efficiency of activity of an economic entity. DEA method allowed identifying the effectiveness of economic measures in healthcare system, as well as provision of the necessary volume of medical services in different countries. A study was conducted to compare the actual effectiveness of the country's medical services to the maximum possible effectiveness. As factor indicators, the summary of health expenditure and its percentage of GDP were considered. The average life expectancy of countries was taken as an average resulting indicator. According to the results, all the surveyed indicators proved to be the most effective measures in providing population with medical services in such countries as Andorra and San Marino, Monaco. It was determined that in order to increase the average life expectancy for one year, an average annual increase in the expenditure on the health care system by $0.48 \%$ of GDP is required.
\end{abstract}

Keywords: life expectancy, health care system, DEA method, health services effectiveness

\section{Introduction}

In order to form Foreign Economic Activity (FEA) of the country in the sphere of healthcare it is necessary to study the effectiveness of health care functioning, as timely detection of problem factors allows to adapt to difficult conditions of changing of foreign economic environment of the country. Flexibility and timely forming of FEA directions are integral factors of preserving the existing and identifying new competitive advantages and, consequently, maintaining or increasing competitiveness.

A significant number of scientific papers is dedicated to study of effectiveness of Integrated Health Care (IHC). IHC focuses on coordinated and integrated health service delivery. The World Health Organization (WHO) defines it as «the management and delivery of health services so that clients receive a continuum of preventive and curative services, according to their needs over time and across different levels of the health system». IHC is also known as coordinated care, comprehensive care, transmural care and seamless care and has been considered as a solution to fragmented and silo forms of healthcare delivery, which do not take into account patient needs and lack communication, connectivity and continuity of care between sectors (The World Health Organization).

But in these and other works on the problem of measuring corporate performance based on the Balanced Scorecard no 
mathematical instruments are proposed to determine the direct level of the activity.

The study of effectiveness of systems of health care is dedicated to the group of scientists (Suter, E., et al., 2017). The scientists have discovered many tools for measuring the quality of care for the patients, interaction of the patient and efficiency of the «team». The researchers identified the existing gap between the tools for measuring the main components, supporting integrated treatment. The authors suggest that the continuation of the improvement of integrated care depends on the capacity to assess the effectiveness of strategies. The level of success of health services, in particular mental health services, depends to a large extent on the level of development of the country. This issue has been studied by the scientists (Semrau, M., et al., 2015). The research was focused on 'Emerging mental health systems in LMICs' (Emerald) program. The program focuses on creating the potential of researchers, policy makers and planners, as well as increasing the level of service for users and carers supporting mental health promotion. Emerald also regards stigma and discrimination as one of the main barriers to access and to successful delivery of health services.

But the issue of quantifying efficiency remains open. Multidimensional methods are used for efficiency analysis, such as: regression analysis, method of comparative analysis, expert estimation method, etc. However, despite their significant number and certain advantages, most of them are based on the calculation of parameters that do not take into account long-term prospects, but only provide an opportunity to summarize the available information. That is why there is a necessity to use a new method giving an opportunity to deliver a complex assessment of activity in the sphere of medical services.

\section{Materials and Methods}

As an example of such method it was suggested to use the method of comparative analysis, i.e. Data Envelopment Analysis (DEA). The methodology of DEA is based on the linear programming for determining the relative efficiency of an economic entity (enterprise) through the implementation of the manufactured products.

According to this interpretation, each set of resources (market inputs) is characterized by a maximum production, and the actual values of market outputs represent the degree of achievement of this maximum. Economic entities that provide maximum market outputs per unit of market inputs acquire the status of the «standard» and form a «threshold of productivity». The task of the analysis is to compare these objects by the efficiency of using their resource base and determining the distance between them and the «threshold of productivity». DEA method is used for this - a relatively new method of measuring performance. An important stage in the evolution of approaches to the measurement of the effectiveness was the research of M. Farrell (Farrell 1957). Concerning the concept of economic efficiency, the scientist suggested that its essence should be regarded as the ratio of actual efficiency to the maximum possible one. In his study M. Farrell estimated the efficiency of a unit of final product with one input and one output parameter. This idea was further developed in 1978, thanks to the work of A. Charns, et al., which reformulated it as a task of mathematical programming.

DEA method is based on the use of linear programming machine. This method eliminates the influence of the executor on determining the weight of each market input and output, eliminating the risk of subjectivity in the assessment. The efficiency criterion in the DEA method is achievement of Pareto's optimum, which is determined by the maximum possible production volume for the existing technological level and supply of resources. DEA method allows: to define an aggregate indicator for each object under study using market inputs to market outputs; to take into account the environmental factors not limited to a function of the linkage between inputs and outputs; to identify the priority directions of productivity growth; evaluate the necessary changes in market inputs/outputs that would allow the object to be brought to the limit of efficiency.

The first DEA model was developed by A. Charnes, Y. Cooper and E. Rhodes (1978). The further development of DEA models is characterized by a two-vector approach according to the magnitude of production. If the productivity of enterprises increases in proportion to the volumes of expended resources, the line on which the research enterprises must be located, sets the constant return scale (CRS) for them. However, if with an increase in the amount of the resource, its return is reduced, the margin of production capacity will look like a curve. In this case, the question is about variable return to scale (VRS). The first vector represents CPR models, according to which the measure of performance is based on an optimally balanced relationship between market inputs and market outputs. The evaluation is carried out in coordinates from 0 (minimum efficiency) to 1 (maximum efficiency). Diagnosis of productivity growth involves a search for alternative options for maximizing the efficiency indicator to 1 .

A significant progress in the use of DEA has been achieved over the past 15 years. The use of DEA is appropriate when testing hypotheses. DEA model can be used to assess a plurality of countries, for example, in the process of analyzing 
the country's health effectiveness. The main features of the economy of service delivery, economies of scale, the logic of the service structure serve to test the model, as well as statistical tests to check the statistical model developed to replicate some basic data generation process.

The possibilities of DEA method for assessing the efficiency are very high. Due to analysis of different types of efficiency taking into account constant and variable magnitude of the scale, a large array of data is obtained, which enables the analysis of health services in countries that have an impact on life expectancy in these countries.

We suggest to use a methodology for assessing health services effectiveness based on the use of health services implemented in different countries. Formally, this algorithm involves solving the optimization problem:

$$
\begin{gathered}
\mathrm{e}_{0}=\frac{\sum_{j=1}^{s} u_{j} y_{j 0}}{\sum_{i=1}^{r} v_{i} x_{i 0}} \rightarrow \max \\
\frac{\sum_{j=1}^{s} u_{j} y_{j m}}{\sum_{i=1}^{r} v_{i} x_{i m}} \leq 1, \quad m=\overline{1, n} \\
u_{j} \geq 0, j=1,2, \ldots, s, \\
v_{i} \geq 0, i=1,2, \ldots, r .
\end{gathered}
$$

where $e_{0}$ - is an indicator of effectiveness of health care activities in the country under study;

$n$ - the number of countries under study;

$r$ - the number of countries included in the comparison range;

$s$ - the number of countries which were selected for the analysis after comparison;

$x_{i 0}$ - the meaning of $i$ market range of the country under study;

$y_{j 0}$ - meaning of $j$ «market output» of the country under study;

$x_{i m}$ - meaning of $i$ input factor of $m$ country;

$y_{i m}$ - meaning of $j$ output parameter of $m$ country;

$v_{i}$ - «weight» of the range of the compared countries $i$;

$u_{j}-$ «weight» of the number of the analyzed countries $j$.

\section{Results and Discussion}

Similar considerations will be applied for the analysis of the level of the countries according to the established criteria.

For a detailed analysis of health care of the countries DEA method will be applied. Research on the efficiency of health care in the countries using DEA method has shown that the achievement of the highest efficiency is not necessarily due to an increase in summary of health expenditure (\% of GDP). Some effective countries often take advantage of other benefits that bring about the development of modern technologies in health and medical tourism system, health insurance system, and other factors.

The indicator of total health expenditure is taken as the percentage of GDP as a factor indicator. As a resulting indicator, the indicator of «average life expectancy» in the countries of the world is taken.

Data processing was carried out in the environment of RStudio using libraries dplyr and Benchmarking, which allow to get the solution to the task. Benchmarketing method, which is often used to perform organizational and inter-country comparisons, was used to compare the countries.

To assess the efficiency of enterprises using DEA it was defined that:

$X$-inputs (indicators of medical services) of the object;

$Y$ - outputs of the object (life expectancy);

EFF - effectiveness according to M. Farrell $(X, Y)$ of the object under study;

SLACK - is a logical vector in which a particular component (for example, the costs) for an object is true with a variable magnitude effect and is equal to 1 , then for the corresponding object is positive, but with a constant effect of scale, the efficiency is close to 0 . Such cases are called weak points of the object or «slacks», which should be taken into account in the analysis. 
VRS - variable returns to scale;

CRS - constant returns to scale;

LAMBDA - is a set of analogs for each object.

Assessment of health care systems of different countries by means of DEA method enabled the use of statistical methods for scaling data, in which thresholds of substitution present observations, and allow to obtain estimates of errors.

53 countries were studied based on the empirical data about medical services in the sphere of healthcare and life expectancy.

The statistical data of health services indicators based on health care expenditures for the period of 2010-2018 was taken, namely: total health care expenditures as a percentage of GDP.

In order to evaluate the results of health care activities in each of the countries reviewed, they were compared with the life expectancy indicator based on the data for the same period of study (2010-2018).

Based on the empirical data on total health expenditure (as a percentage of GDP) and life expectancy, the healthcare system efficiency boundary has been constructed, which allows for assessment of the outcomes of activity of each country considered.

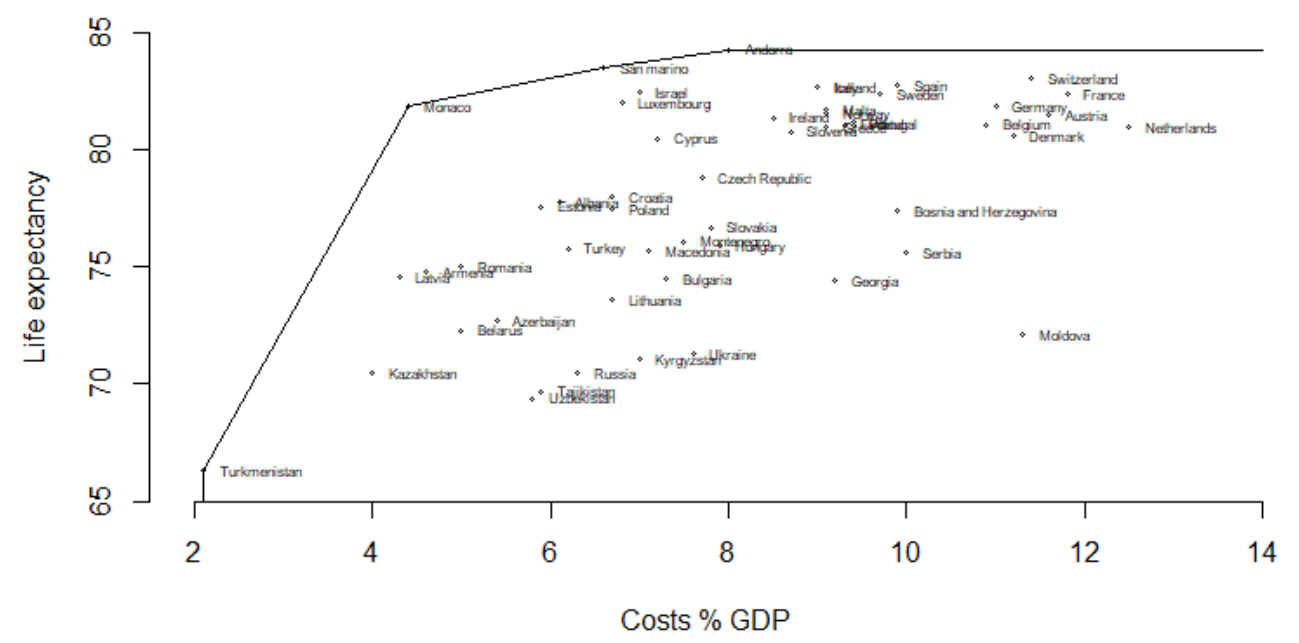

Figure 1. Health efficiency curve according to the indicator of total health expenditure (percentage of GDP) Developed by the authors.

\section{Conclusion}

Among 53 countries studied, one can observe a significant heterogeneity in both constant (CRS) and variable (VRS) effect. The results of DEA are given below DEA (Table 1). 
Table 1. Health efficiency index according to health expenditure (percentage of GDP)

\begin{tabular}{ccc}
\hline $\begin{array}{c}\text { Efficiency Index } \\
\text { (interval) }\end{array}$ & Number of countries & $\begin{array}{c}\text { Relative Number of } \\
\text { Countries }(\%)\end{array}$ \\
\hline$[0.2 ; 0.3)$ & 1 & 1.9 \\
{$[0.3 ; 0.4)$} & 8 & 15.1 \\
{$[0.4 ; 0.5)$} & 19 & 35.8 \\
{$[0.5 ; 0.6)$} & 11 & 20.8 \\
{$[0.6 ; 0.7)$} & 7 & 13.2 \\
{$[0.7 ; 0.8)$} & 3 & 5.7 \\
{$[0.8 ; 0.9)$} & 0 & 0 \\
{$[0.9 ; 1)$} & 0 & 0 \\
1 & 4 & 7.5 \\
\hline
\end{tabular}

Developed by the authors

As you can see, there are only 4 countries with efficiency 1 (on the graph these countries are on the efficiency curve), 3 countries with efficiency from 0.7 to $0.8,7$ countries with efficiency from 0.6 to 0.7 . It should be noted that health services efficiency on the base of total health expenditure (as a percentage of GDP) of Ukraine is 0.42. Consequently, there is an enormous potential for improving the effectiveness of this category of health services in a large number of countries.

According to the results of the model implementation, we conclude that the model is adequate, the null hypothesis is rejected. The coefficients of regression have a high level of significance.

The significance of regression coefficients in the model is confirmed by Student's t-statistics. An explanation of the level of relative statistical quality of the developed model is the fact that it has significant coefficients of the equations according to Student's t-statistic criterion and adequately describes the process, which is confirmed by Fisher's (F) statistics, has a sufficient value for the determination coefficient (R2), and Durbin-Watson criterion (DW) indicates the presence of autocorrelation of residues, which negatively affects the predictive ability of the model. Thus, the determination coefficient constitutes 0.69 , in other words life expectancy is explained by the factors mentioned on an average by $69 \%$.

The impact of health expenditure on health care in percentage of GDP has been studied.

Thus, such countries as Andorra, San Marino, Monaco are among the countries with the highest health efficiency indicators according to health expenditure (\% of GDP).

The results of the analysis allow to conclude that the most effective measures, according to all the indicators studied, are in Andorra and San Marino.

The conducted analysis allows us to conclude that in order to increase the average life expectancy for one year it is necessary to increase health expenditure by $0.48 \%$ of GDP on average. It is clear that such an increase in health expenditures may not produce the same effect in the same year, but it will take some time.

\section{References}

Babenko, V. (2019). Formalization of the Model of Management of the Technological Innovations. CEUR Workshop Proceedings, 2393, 595-602. Retrieved from http://ceur-ws.org/Vol-2393/paper_431.pdf

Babenko, V., Perevozova, I., Mandych, O., Kvyatko, T., Maliy, O., \& Mykolenko, I. (2019). World informatization in conditions of international globalization: factors of influence. Global Journal of Environmental Science and Management, 5(SI), 172-179. https://doi.org/10.22034/gjesm.2019.05.SI.19

Bautista, M., Nurjono, M., Wei Lim, Y., Dessers, E., \& Vrijhoef, H. (2016). Instruments measuring integrated care: A systematic review of measurement properties. Milbank Quarterly, 94, 862-917.

Berkovits, Ye., Boll, R., Vnukova, N., Vovk, Ya., Hariacha, O., Hamankova, O., \& Savchenko, A. (2015). Neobkhidnist reformuvannia systemy medychnoho strakhuvannia $v$ Ukraini [Necessity of the medical insurance system reforming in Ukraine]. Yurydychnyi visnyk, 3, 187 [in Ukrainian].

Charnes, A., Cooper, W. W., \& Rhodes, E. Measuring the efficiency of decision making units. Retrieved 15 January 2019, from https://www.utdallas.edu/ ryoung/phdseminar/CCR1978.pdf 
Drummond, M., Sculpher, M., Claxton, K., Stoddart, G., \& Torrance, G. (2015). Methods for the economic evaluation of health care programs. Oxford University Press.

Farrell, M. (1957). The measurement of productive efficiency. Journal of the Royal Statistical Society, Series A, $120(3), 253-290$.

Ghiselline, P., Cialani, C., \& Ulgiati, S. (2016). A review on circular economy: the expected transition to a balanced interplay of environmental and economic systems. Journal of Cleaner Production, 114, 11-32.

Ginter, P., Duncan, W., \& Swayne, L. (2018). The strategic management of healthcare organizations. John Wiley \& Sons.

Hastings, S., Armitage, G., Mallinson, S., Jackson, K., \& Suter, E. (2014). Exploring the relationship between governance mechanisms in healthcare and health workforce outcomes: a systematic review. BMC Health Services Research, 14(1).

Karpyshyn, N. (2017). Shliakhy optymizatsii finansovoho zabezpechennia okhorony zdorovia v Ukraini [Ways of optimization of healthcare financial providing in Ukraine]. Svit finansiv, 4(21), 99-104 [in Ukrainian].

Lekhan, V., Volchek, V., Kriachkova, L., \& Kyi-Kokarieva, V. (2016). Intehratsiia medychnoi dopomohy yak tekhnolohiia pidvyshchennia efektyvnosti systemy okhorony zdorovia [Integration of medical care as a technology for increasing the health care system efficiency]. Ekonomika i pravo okhorony zdorovia, 1, 5-11 [in Ukrainian].

Liu, J., Mooney, H., Hull, V., Davis, S., Gaskell, J., Hertel, T., \& Li, S. (2015). Systems integration for global sustainability. Science, 347(6225), 125-132.

Lyngso, A., Godtfredsen, N., Host, D., \& Frolich, A. (2014). Instruments to assess integrated care: A systematic review. International Journal of Integrated Care, 14(1-15).

Ramazanov, S., Antoshkina, L., Babenko, V., \& Akhmedov, R. (2019). Integrated model of stochastic dynamics for control of a socio-ecological-oriented innovation economy. Periodicals of Engineering and Natural Sciences, 7(2), 763-773. https://doi.org/10.21533/pen.v7i2.557

Reddy, S. (2015). Towards better healthcare integration. The Health Leader, 30-31.

Semrau, M., Evans-Lacko, S., Alem, A., Ayuso-Mateos, J., Chisholm, D., Gureje, O., \& Lund, C. (2015). Strengthening mental health systems in low-and middle-income countries: the Emerald program. BMC Medicine, 13(1), 39-79.

Shevchenko, V. (2017). Problemy otsinky efektyvnosti upravlinnia zakladamy okhorony zdorovia v Ukraini [Evaluation problems of professional management efficiency of health care establishments in Ukraine], 64, 117 [in Ukrainian].

Suter, E., Oelke, N., de Silva, L., Stiphout, M., Janke, R., Witt, R., \& Birney, A. (2017). Indicators and measurement tools for health systems integration. A Knowledge Synthesis. International Journal of Integrated Care, 17(6).

The World Health Organization. Retrieved March 2019, from http://apps.who.int/iris/handle/10665/127502/browse?localeattribute=ru\&type=dateissued

Trofymenko, H. (2014). Dosvid ratsionalnoi orhanizatsii rozvytku struktur u haluzi okhorony zdorovia [The experience of a rational organization of development of healthcare structures]. Skhid, 1, 104-107 [in Ukrainian].

Trofymenko, H. (2014). Modeliuvannia upravlinnia ta orhanizatsii okhorony zdorovia [Modeling of management and organization of health care]. Innovatsiina ekonomika, 2, 193-197 [in Ukrainian].

Tukey, J. (1977). Exploratory Data Analysis. Addiso-Wesley. 